\title{
MEASUREMENT SYSTEMS OF SOIL WATER MATRIC POTENTIAL AND EVALUATION OF SOIL MOISTURE UNDER DIFFERENT IRRIGATION DEPTHS
}

\author{
JOSÉ M. G. BERALDO ${ }^{1}$, JOSÉ E. CORA ${ }^{2}$, EDEMO J. FERNANDES ${ }^{3}$
}

\begin{abstract}
The development of new methodologies and tools that enable to determine the water content in soil is of fundamental importance to the practice of irrigation. The objective of this study was to evaluate soil matric potential using mercury tensiometer and puncture digital tensiometer, and to compare the gravimetric soil moisture values obtained by tensiometric system with gravimetric soil moisture obtained by neutron attenuation technique. Four experimental plots were maintained with different soil moisture by irrigation. Three repetitions of each type of tensiometer were installed at $0.20 \mathrm{~m}$ depth. Based on the soil matric potential and the soil water retention curve, the corresponding gravimetric soil moisture was determined. The data was then compared to those obtained by neutron attenuation technique. The results showed that both tensiometric methods showed no difference under soil matric potential higher than $-40 \mathrm{kPa}$. However, under drier soil, when the water was replaced by irrigation, the soil matric potential of the puncture digital tensiometer was less than those of the mercury tensiometer.
\end{abstract}

KEYWORDS: tensiometer, digital tensiometer, neutron attenuation technique.

\section{SISTEMAS DE LEITURA DO POTENCIAL MÁTRICO DA ÁGUA NO SOLO E AVALIAÇÃO DA UMIDADE DO SOLO SOB DIFERENTES LÂMINAS DE IRRIGAÇÃO}

RESUMO: O desenvolvimento de novas metodologias e instrumentos que possibilitem determinar o conteúdo de água no solo é de fundamental importância para a prática de irrigação. $\mathrm{O}$ estudo teve por objetivo avaliar a eficiência do tensiômetro de punção e a leitura digital em relação ao tensiômetro de coluna de mercúrio e leitura analógica, na obtenção do potencial mátrico, e comparar os valores da umidade do solo obtidos a partir da tensiometria com a técnica da moderação de nêutrons. Foram aplicadas em quatro parcelas experimentais as lâminas de água (de 238,$9 ; 159,8 ; 118,2$ e $65,0 \mathrm{~mm}$ ). Três repetições de cada tipo de tensiômetro e o sistema de leitura foram instalados na profundidade de $0,20 \mathrm{~m}$. A partir dos valores do potencial mátrico obtidos pelos tensiômetros e pela curva de retenção de água no solo, foi determinada a umidade do solo, e os dados foram comparados com a técnica da moderação de nêutrons. O potencial mátrico da água no solo, medido pelo tensiômetro de punção de leitura digital, não apresentou diferença em relação aos valores obtidos pelo tensiômetro de mercúrio, em potenciais mátricos maiores que $-40 \mathrm{kPa}$. Com ciclos de umedecimento e secamento do solo, o potencial mátrico obtido pelo tensiômetro de punção com leitura digital foi menor do que os valores obtidos pelo tensiômetro de mercúrio.

PALAVRAS-CHAVE: tensiômetro, tensímetro digital, técnica de moderação de nêutrons.

\footnotetext{
${ }^{1}$ Professor Doutor, Instituto Federal de Educação, Ciência e Tecnologia de São Paulo, IFSP/Câmpus Avançado de Matão, Matão-SP, jmgberaldo@ifsp.edu.br.

${ }^{2}$ Professor Adjunto, Departamento de Solos e Adubos, FCAV/UNESP, Câmpus de Jaboticabal - SP, cora@fcav.unesp.br.

${ }^{3}$ Professor Adjunto, Departamento de Engenharia Rural FCAV/UNESP, Câmpus de Jaboticabal - SP.

Recebido pelo Conselho Editorial em: 29-11-2010

Aprovado pelo Conselho Editorial em: 7-1-2012
} 


\section{INTRODUCTION}

The soil has the capacity to store water in its pores and provide part of it to the plants to the extent of their needs. Through monitoring of matric water potential in the ground, it is possible to determine the amount of water needed to be replaced to the plants by irrigation. The appropriate irrigation can significantly reduce the amount of water applied, in order to minimize loss of water and soil, increase crop yield and reduce production costs.

There are direct and indirect methods to determine soil moisture. The best known direct method is the gravimetric method and, among the indirect, it has the electrical resistance blocks, neutron probe, gamma radiation, tensiometry, psychrometrics, computed tomography and time domain reflectometry (ALBUQUERQUE \& DURÃES, 2008).

The gravimetric method is considered standard, however, involves collecting soil samples for each measure, making it laborious and impacting to the environment, because of the constant removal of soil from the area. This method does not allow the measure replicates in the same place, therefore, it is not suitable for evaluation which require many steps over time (CICHOTA et al., 2008).

There are three direct ways to measure the influence of soil water content on matric potential. They are: Richards pressure chamber, Haines funnel and tensiometer (LIBARDI, 2005).

Although the three methods use a porous plate, the only one that allows direct measurement in the field is the tensiometer. Its working principle is based on the balance between the capillary forces and adsorption which occur because of the interaction between water and solid soil particles.

The use of a tensiometer has the advantage of indicating the time and amount of irrigation water to be applied to the soil, which requires knowledge of soil water retention curve.

Since its inception, the original version of the tensiometer has been showing modifications (WHALLEY et al., 2009), especially in the reading system and the constituent materials, which have as their objective to facilitate the installation of equipment in the field, improve its operation, maintenance and response time, and facilitate reading by the operator.

The reading system may be indicated by a manometer in the form of U-tube with water or mercury, or a mechanical or electrical indicator (REICHARDT \& TIMM 2004).

The conventional tensiometer uses as reading system the mercury column manometer, and a direct measurement of matric potential. However, it has disadvantages, such as toxicity of mercury, the manual accomplishment of readings, with the possibility of visual error in reading by the operator, and the need for constant maintenance of the apparatus to eliminate air bubbles inside the tensiometer.

The tensiometer of mercury manometer is used for research purposes, however, for practical purposes, as its use in the field, presents operational difficulties. Thus, it is necessary to evaluate a reading system that facilitates its use.

To facilitate the operation and maintenance of a tensiometer, a pressure transducer with digital reading (MARTHALER et al., 1983) has been developed, which measures the tension in the tensiometric tube, and whose values are displayed on a digital display.

The development of new methodologies and tools that allow determining the soil water content is of great importance for agronomic knowledge and scientific research (TEIXEIRA et al., 2005).

Another technique for determining the soil water content is the neutron moderation, which allows the soil water content to be obtained directly, with minimal change in the soil profile, at any time and in a fast and practical way. Its disadvantage is the cost of equipment. However, few studies in the literature compare the effectiveness of these technologies in the determination of soil water content. 
Given the above, the hypothesis of this study is that the soil water matric potential measured by puncture digital tensiometer shows no difference compared to values obtained by mercury tensiometer and soil moisture determined by tensiometry and soil water retention curve does not differ from that obtained by the technique of neutron moderation.

The objective was to evaluate the efficiency of digital tensiometer in relation to an analog mercury tensiometer, in obtaining the matric potential, and compare the values of soil moisture obtained from tensiometry with the technique of neutron moderation.

\section{MATERIAL AND METHODS}

The experiment was conducted in an experimental area of Faculty of Agriculture and Veterinary Sciences (FCAV), UNESP, Jaboticabal, State of São Paulo, Brazil (21 14 '51' S and $\left.48^{\circ} 16^{\prime} 58^{\prime \prime} \mathrm{W}\right)$. The experimental area was classified as an Oxisol (EMBRAPA, 2006), whose physical attributes are presented in Table 1.

For determination of granulometric fractions of soil samples, it was used the pipette method (GEE \& BAUDER, 1986). For analysis of soil bulk density, total porosity, macroporosity and microporosity of the soil, it was used the method proposed by EMBRAPA (1997).

To conduct this study, it was selected four plots (P1, P2, P3 and P4) of a larger experiment which aimed to evaluate different methods to determine the height of the irrigation depths for irrigation of common bean. The culture was established in June 2008, conventional tillage in the conventional manner (chiseling and disking). The bean cultivar Carioca was used, spaced $0.45 \mathrm{~m}$ between rows.

TABLE 1. Mean values for granulometric analysis, bulk density (BD), total porosity (Pt), soil macroporosity (Ma) and soil microporosity (Mi) from the soil layer of $0.0-0.20 \mathrm{~m} *$.

\begin{tabular}{cccccccc}
\hline Plot & Clay & Silt & Sand & BD & Pt & Ma & Mi \\
\hline & $-------\mathrm{g} \mathrm{kg}^{-1}$ & ------- & $\mathrm{Mg} \mathrm{m}^{-3}$ & $-----------\mathrm{m}^{3} \mathrm{~m}^{-3}------------$ \\
P1 & 438 & 188 & 374 & 1.24 & 0.54 & 0.15 & 0.38 \\
P2 & 488 & 177 & 335 & 1.21 & 0.56 & 0.17 & 0.39 \\
P3 & 430 & 190 & 380 & 1.28 & 0.51 & 0.12 & 0.39 \\
P4 & 492 & 166 & 342 & 1.41 & 0.50 & 0.07 & 0.43 \\
\hline
\end{tabular}

*The values are mean of 3 repetitions per plot.

Each plot occupied an area of 864 square meters ( $54 \mathrm{~m}$ long by $16 \mathrm{~m}$ wide). The borders of the plots corresponded to the initial and final $9 \mathrm{~m}$ length and $4 \mathrm{~m}$ from the sides, leaving the floor area of each plot with $288 \mathrm{~m}^{2}(36 \mathrm{~m} \times 8 \mathrm{~m})$.

In the plots $\mathrm{P} 1$ and $\mathrm{P} 2$, the irrigation depths were determined by estimating the maximum evapotranspiration of the bean and tensiometry. The methodology adopted for the onset, frequency and volume of irrigation depths applied to the plots is described in FERNANDES (2008).

The plots P3 and P4 were subjected to four and two irrigations, as shown in Table 2, in order to obtain variation in soil water content in relation to other plots.

The amounts of water, applied to each portion (irrigation depth) by a conventional irrigation system, were measured using a set of twelve manometers and their mean values, as well as precipitation occurred during the experiment (Table 2).

To evaluate the uniformity of water distribution, it was used the uniformity coefficient of CHRISTIANSEN (1942), whose mean value was $87.9 \%$, therefore, within the minimum value adopted as reference for the system of irrigation, which is $80 \%$. 
TABLE 2. Mean values from irrigation depths applied to the experimental plots and rainfall between June $24^{\text {th }}$ and September $1^{\text {st }}, 2008$.

\begin{tabular}{|c|c|c|c|c|c|}
\hline \multirow{2}{*}{ Date } & \multirow{2}{*}{ Rainfall } & \multicolumn{4}{|c|}{ Irrigation depths (mm) } \\
\hline & & P1 & $\mathrm{P} 2$ & P3 & P4 \\
\hline June $24^{\text {th }}$ & & 30.00 & 30.00 & 30.00 & 30.00 \\
\hline July $4^{\text {th }}$ & & 22.60 & & & \\
\hline July $11^{\text {th }}$ & & 15.40 & & & \\
\hline July $15^{\text {th }}$ & & 18.50 & & & \\
\hline July $23^{\text {rd }}$ & & 31.50 & & & \\
\hline July $25^{\text {th }}$ & & & 58.55 & & \\
\hline July $28^{\text {th }}$ & & 23.60 & & & \\
\hline July $30^{\text {th }}$ & & & & 37.67 & 35.00 \\
\hline August $1^{\text {st }}$ & & 22.20 & & & \\
\hline August $4^{\text {th }}$ & 5.80 & & & & \\
\hline August $5^{\text {th }}$ & 13.70 & & & & \\
\hline August $11^{\text {th }}$ & 2.50 & & & & \\
\hline August $12^{\text {th }}$ & & & & 28.83 & \\
\hline August $13^{\text {th }}$ & & 21.60 & 34.25 & 21.70 & \\
\hline August $18^{\text {th }}$ & & 27.60 & & & \\
\hline August $22^{\text {nd }}$ & & & 37.00 & & \\
\hline August $25^{\text {th }}$ & & 25.90 & & & \\
\hline September $1^{\text {st }}$ & 1.70 & & & & \\
\hline Total & 23.70 & 238.90 & 159.80 & 118.20 & 65.00 \\
\hline
\end{tabular}

15 days after crop emergence, it was installed in the center of the plots and between the crop rows, three repetitions of the column analog mercury tensiometer and three digital tensiometer, totaling four parcels, 12 tensiometers of each reading system.

The tensiometer was installed at a depth of $0.20 \mathrm{~m}$ with the aid of an auger screw, one beside the other, in row, $0.15 \mathrm{~m}$ apart from each other, alternately (in pairs), i.e., a mercury tensiometer followed by a digital tensiometer. The repetitions were far apart in the $9 \mathrm{~m}$ plot.

The capsules of the ceramic tensiometers were submitted to bubbling test, which was consisted of subjecting the capsules to pressure increases, with the reference values of more than $100 \mathrm{kPa}$.

The readings of matric potential began 20 days after crop emergence, held daily from 7:00h and 8:00h, for a period of 52 days. The values of soil water matric potential, measured in $\mathrm{mm}$ of $\mathrm{Hg}$ with the mercury tensiometer, were processed and corrected to kPa by eq.(1):

$$
\Psi \mathrm{m}=\left(-12,6 \mathrm{~h}_{1}+\mathrm{h}_{2}+\mathrm{h}_{3}\right) 0.0981
$$

In which:

$\Psi \mathrm{m}$ - soil water matric potential, $\mathrm{kPa}$;

$\mathrm{h}_{1}$ - manometric height of the mercury column, $\mathrm{cm}$;

$\mathrm{h}_{2}$ - height from the mercury surface in the recipient to the soil surface, $\mathrm{cm}$; and

$\mathrm{h}_{3}$ - tensiometer installation depth considered from the soil surface to the porous capsule center, $\mathrm{cm}$. The value 0.0981 represents the transformation factor from $\mathrm{cm}$ of water column to $\mathrm{kPa}$.

The values of soil water matric potential measured with the puncture digital tensiometer were converted to $\mathrm{kPa}$ and corrected by the eq.(2):

$$
\Psi \mathrm{m}_{\text {Dig }}=\left[(1019 \mathrm{~L})+\left(\mathrm{h}_{1}+\mathrm{h}_{2}\right)\right] 0.0981
$$


In which:

$\Psi \mathrm{m}$ - soil water matric potential, $\mathrm{kPa}$;

$\mathrm{L}$ - tensiometer reading, bar;

$\mathrm{h}_{1}$ - water column of the soil surface until the water level of the transparent tube, $\mathrm{cm}$; and

$\mathrm{h}_{2}$ - tensiometer installation depth from the soil surface to the porous capsule center, $\mathrm{cm}$. The value 0.0981 represents the transformation factor from $\mathrm{cm}$ of water column to $\mathrm{kPa}$.

The puncture digital tensiometer used was of the Hydrodynamics brand, whose voltagereading unit is provided in CBAR by means of a digital display.

In order to assess the reliability of the values of soil water matric potential obtained by puncture digital tensiometer, it was made its calibration in the laboratory. For this, a tensiometer was constructed to allow both reading systems, mercury manometer and puncture digital tensiometer, to work together in the same tensiometric tube. The matric potential values measured by both reading systems were equivalent, indicating reliability of the values obtained by the digital tensiometer (Figure 1).

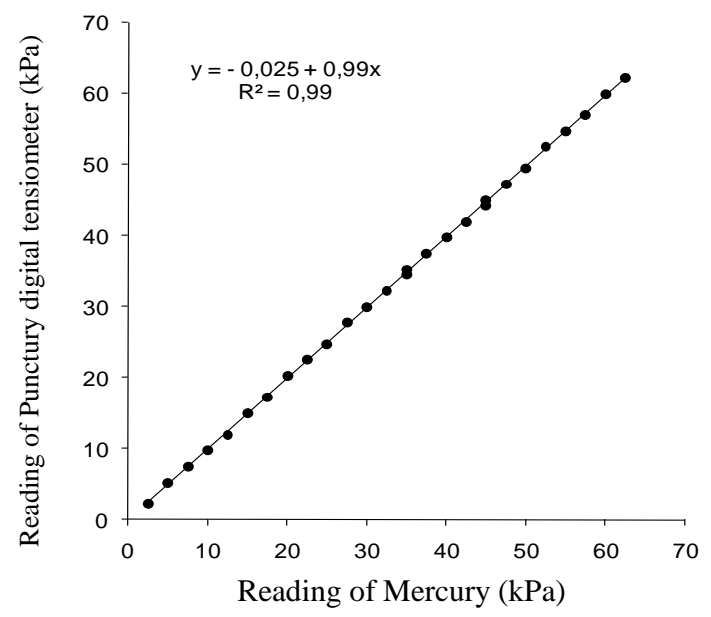

FIGURE 1. Calibration of digital tensiometer reading system.

As the tensiometer does not provide direct reading of soil moisture, it was determined indirectly from the characteristic curve of soil water retention. For this, it was collected undisturbed soil samples from each experimental plot in a depth of $0-0.20 \mathrm{~m}$ in three replications. The samples were subjected to the tensions progressively $0.001 ; 0.002 ; 0.003 ; 0.004 ; 0.005 ; 0.006 ; 0.007 ; 0.008$; 0.009 and $0.01 \mathrm{MPa}$, using a tension table, and to the tensions of $0.03 ; 0.06 ; 0.1 ; 0.3$ and $1.5 \mathrm{MPa}$ using the Richards pressure chamber with the porous plate (KLUTE, 1986).

The water retention in tension of 1.5 MPa was determined in deformed samples of soil, following the method proposed by EMBRAPA (1997). Subsequently, an adjustment was made of data of the water content retained in the different tensions by the model of GENUCHTEN (1980).

Additionally, with the aim of measuring soil moisture by neutron moderation technique, an aluminum access tube was installed with internal diameter of $0.048 \mathrm{~m}$ and length of $1.9 \mathrm{~m}$ in each experimental plot. The access tube was installed on the same line where the tensiometer were installed and located between the second and third repetitions of tensiometers, i.e., $4.5 \mathrm{~m}$ away from each tensiometers repetition. The model of the neutron probe equipment used was 503 DR Hydroprobe of CPN Corporation, ${ }^{241} \mathrm{Am} / \mathrm{Be}$ source of neutrons and radioactive intensity of $1.85 \mathrm{GBq}$. The time to obtain neutron counts was 32 seconds and was based on experimental results obtained by BERALDO et al. (2009).

The methodology for calibration of a neutron probe consisted primarily of counting neutrons in water, as standard, and then in the soil, to obtain the relative neutron count (RC), which is defined as the ratio of soil neutron count and water neutron count. 
The neutron probe calibration was performed under field conditions. Two access tubes were installed, one irrigated with frequency and the other kept free of irrigation, in order to obtain variations in the soil water conditions. The RC measurements were obtained at a depth of 0-0.20 m, with eighteen repetitions. After the determinations, deformed soil samples were taken using volumetric rings to determine the gravimetric soil moisture in the laboratory.

From the values of RC and gravimetric soil moisture (average of 18 data pairs), the linear regression equation was obtained, as shown by equation 3 :

$$
\theta=-0.068+0.7802 \mathrm{RC} \quad \mathrm{R}^{2}=0.95
$$

In which:

$\theta$ - gravimetric soil moisture in the layer of $0-0.20 \mathrm{~m}$, and

$\mathrm{RC}$ - relative neutron count.

It was performed analysis of correlation and regression between the matric potential values obtained by the mercury tensiometer and the puncture digital tensiometer. Two statistical indices were used to quantify the differences between changes in soil water matric potential obtained by the two reading systems, they being the correlation coefficient (r) and the concordance index (d), proposed by WILLMOTT et al. (1985).

Because the statistical indexes do not quantify the errors, the indicators of mean absolute error (MAE) were certain, the square root of mean square error (SRMSE) and efficiency (EF) as ZACHARIAS et al. (1996). The matric potential values obtained from the mercury tensiometer were considered as reference for comparison between the reading systems.

\section{RESULTS AND DISCUSSION}

The values of soil water matric potential obtained by the tensiometers ranged from -5 to -80 $\mathrm{kPa}$ (Figure 2). From values of matric potential lower than $-80 \mathrm{kPa}$ it was not possible to obtain readings measured by tensiometry. This is due to the action of matric forces acting on the soil, causing a gradient of potential energy which causes water to flow from within the capsule into the soil, i.e., from a higher energy place to a place with lower energy. As a result of transfer of energy, the air contained in the soil is able to pass through the porous capsule wall, causing breakage of the equilibrium column between the water contained inside the tensiometric tube and the soil water. This was observed in plots P2, P3 and P4 in the period between July $21^{\text {st }}$ and $29^{\text {th }}, 2008$, because, in this period, values of soil water matric potential lower than or equal to $-80 \mathrm{kPa}$ were recorded, the limit value of reading tensiometer (Figure 2).

The values of soil water matric potential in P1 remained the same, with greater frequency in potential greater than $-40 \mathrm{kPa}$, i.e., more humid conditions, as was expected due to the higher frequency of irrigation and greater irrigation depth applied in this plot.

It was observed similar values of water matric potential between the reading systems when these were kept at up to $-40 \mathrm{kPa}$ (Figure 2). In periods in which occurred soil drying with subsequent replacement of the water, the greatest differences were observed between the values of the readings of tensiometers with different reading systems, as may be seen on July $25^{\text {th }}$, shortly after irrigation (Figure 2) and in the evaluation period from June $25^{\text {th }}$ to July $15^{\text {th }}$. 
(a)

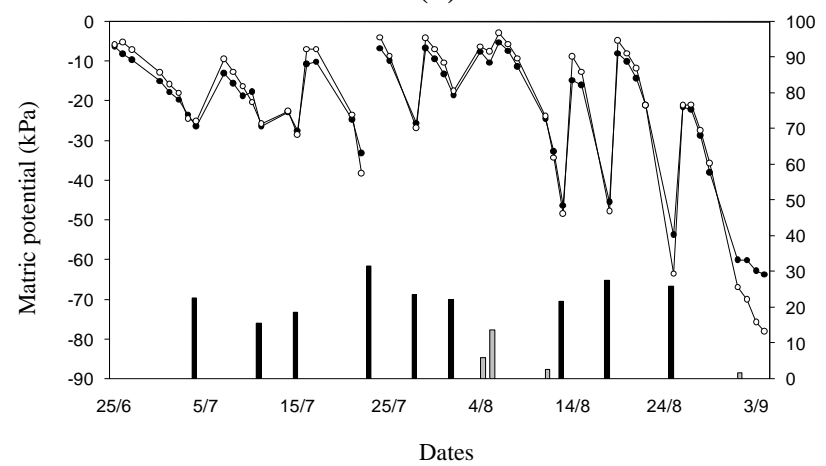

(c)

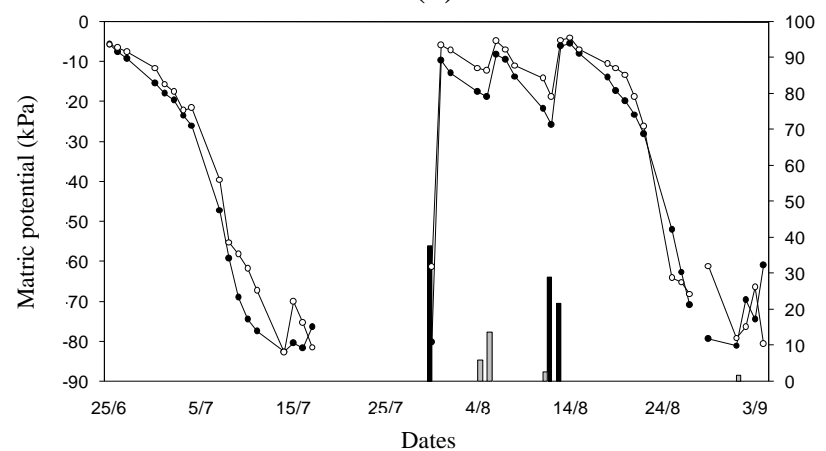

(b)

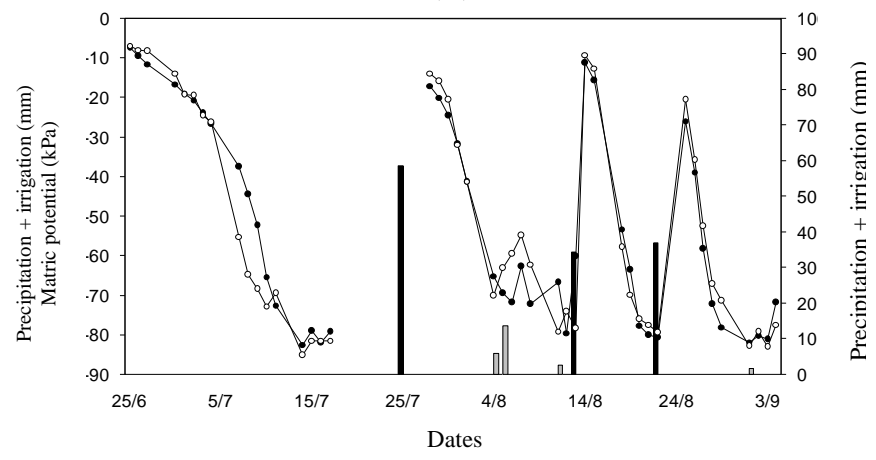

(d)

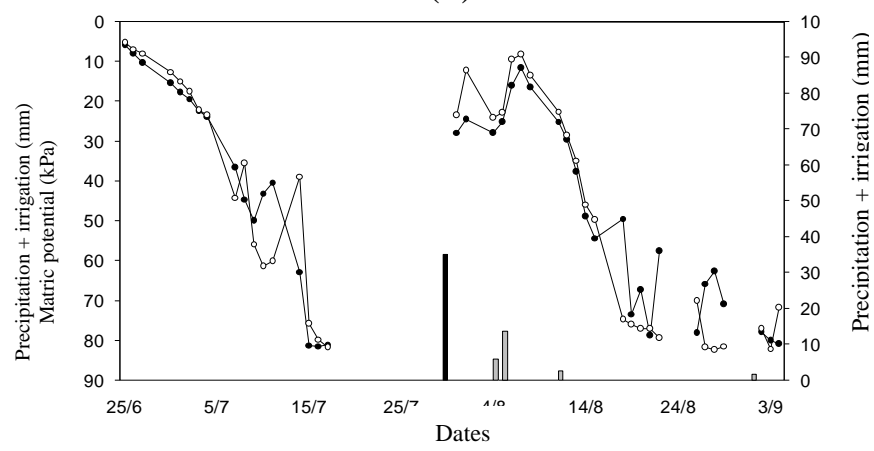

Irrigation $(\mathrm{mm}) \square$ Precipitation $(\mathrm{mm}) \bullet-T e n s \mathrm{Hg} \stackrel{-}{ }-$ Tens Dig

FIGURE 2. Soil water matric potential measured by the mercury tensiometer (Tens $\mathrm{Hg}$ ) and puncture digital tensiometer (TensDig) in plots P1 (a) P2 (b), P3 (c) and P4 (d).

ASSIS JÚNIOR \& REICHARDT (1997) observed in field work that the response of the mercury tensiometer and the air chamber tensiometer was similar, but in a condition in which the values of soil water matric potential were greater than $-40 \mathrm{kPa}$.

It was observed lower amplitude between the values obtained by the mercury tensiometer and puncture digital tensiometer when the matric potential was less than $-40 \mathrm{kPa}$ when compared with the mean amplitude during periods where the value of matric potential was higher than $-40 \mathrm{kPa}$ (Table 3).

In periods in which the value of matric potential was lower than $-40 \mathrm{kPa}$ the mean amplitude (in modulus) ranged from 1.3 to $2.1 \mathrm{kPa}$, whereas when the value of matric potential was higher than $-40 \mathrm{kPa}$, the mean amplitude ranged from 8.0 to $12.9 \mathrm{kPa}$, so a great difference between reading systems for the matric potential, when one takes into account the ranges above and below $-40 \mathrm{kPa}$. With progressive cycles of wetting and drying, the air volume inside the tensiometer changes, which causes a failure of the device response (MARINHO et al., 2008).

COELHO \& TEIXEIRA (2004) found that errors in the values of matric potential, obtained by mercury tensiometer, as well as a tensiometer comprising an electronic circuit and a differential pressure sensor, tend to be more evident as the matric potential decreases, i.e., when the soil dries.

Under conditions of wetting and drying of the soil, the utilization of a capacitive sensor which has extreme values of dielectric constant in different environments (air and water) showed low response time to variations in soil water content (CRUZ et al. 2010), thus constituting an alternative to estimating the soil water content under conditions of wetting and drying soil. 
TABLE 3. Amplitude between the soil water matric potential (module) by mercury tensiometer and puncture digital tensiometer separated by range intervals.

\begin{tabular}{|c|c|c|c|c|c|}
\hline \multirow{3}{*}{ Date } & \multirow{3}{*}{ Interval } & \multicolumn{4}{|c|}{ Plot } \\
\hline & & P1 & P2 & P3 & $\mathrm{P} 4$ \\
\hline & & \multicolumn{4}{|c|}{------------- kPa ------------- } \\
\hline June $25^{\text {th }}$ & \multirow{15}{*}{ Lower than $-40 \mathrm{kPa}$} & 0.4 & 0.5 & 0.2 & 0.6 \\
\hline June $26^{\text {th }}$ & & 3.0 & 1.6 & 1.0 & 1.2 \\
\hline June $27^{\text {th }}$ & & 2.5 & 3.3 & 1.8 & 2.4 \\
\hline June $30^{\text {th }}$ & & 2.0 & 2.7 & 3.8 & 3.0 \\
\hline July $1^{\text {st }}$ & & 1.8 & 0.2 & 2.4 & 2.9 \\
\hline July $2^{\text {nd }}$ & & 1.7 & 1.1 & 2.1 & 1.8 \\
\hline July $3^{\text {rd }}$ & & 1.1 & 0.7 & 1.2 & 0.1 \\
\hline July $4^{\text {th }}$ & & 1.3 & 0.4 & 4.4 & 0.2 \\
\hline July $7^{\text {th }}$ & & 3.5 & $*$ & $*$ & $*$ \\
\hline July $8^{\text {th }}$ & & 3.1 & $*$ & $*$ & $*$ \\
\hline July $9^{\text {th }}$ & & 2.7 & $*$ & $*$ & $*$ \\
\hline July $10^{\text {th }}$ & & 2.5 & $*$ & $*$ & $*$ \\
\hline July $11^{\text {th }}$ & & 0.6 & $*$ & $*$ & $*$ \\
\hline July $14^{\text {th }}$ & & 0.2 & $*$ & $*$ & $*$ \\
\hline July $15^{\text {th }}$ & & 1.1 & $*$ & $*$ & $*$ \\
\hline Mean & & 1.7 & 1.3 & 2.1 & 1.5 \\
\hline July $7^{\text {th }}$ & \multirow{8}{*}{ Higher than $-40 \mathrm{kPa}$} & $* *$ & 17.7 & 7.7 & 7.6 \\
\hline July $8^{\text {th }}$ & & $* *$ & 20.3 & 4.2 & 9.1 \\
\hline July $9^{\text {th }}$ & & $* *$ & 16.2 & 10.7 & 5.8 \\
\hline July $10^{\text {th }}$ & & $* *$ & 7.5 & 12.8 & 18.4 \\
\hline July $11^{\text {th }}$ & & $* *$ & 3.1 & 10.2 & 19.8 \\
\hline July $14^{\text {th }}$ & & $* *$ & 2.6 & 0.3 & 24.0 \\
\hline July $15^{\text {th }}$ & & $* *$ & 2.4 & 10.4 & 5.5 \\
\hline Média & & $* *$ & 10.0 & 8.0 & 12.9 \\
\hline
\end{tabular}

*Values higher than $-40 \mathrm{kPa}$; ** Values lower than $-40 \mathrm{kPa}$.

In most of the dates evaluated in this study, the values of the matric potential measured by the puncture digital tensiometer were higher (less negative) when compared with those obtained using the mercury tensiometer (Figure 2). Similar results were observed by MORAES et al. (2006) and BRITO et al. (2009). This result may be attributed to a slight increase in potential, in the moment the silicone rubber is pierced by the needle of the tensiometer, because, with the insertion of the needle, the volume of air inside the tensiometric tube is changed.

The lowest and highest coefficient of determination $\left(\mathrm{R}^{2}\right)$ between the values of soil water matric potential measured by the two reading systems have been observed in the plots P1 and P4, respectively. This fact shows that the potential values observed are similar when the soil is more humid and they are most disparate in drier soil conditions (Figure 3).

These results corroborate the results found by MARTHALER et al. (1983), who obtained a high coefficient of determination $\left(\mathrm{R}^{2}=0.99\right)$ between the readings of soil matric potential measured with a mercury tensiometer and digital pressure transducer. The authors attributed the results to higher frequency of irrigation that kept the soil moist.

Also in Figure 3, it can be observed that the greatest data scattering in relation to the line 1:1 occurred for values of matric potential lower than $-40 \mathrm{kPa}$, confirming that this was the value from which occurred the greatest differences between the values of soil matric potential measured by the two systems. 
(a)

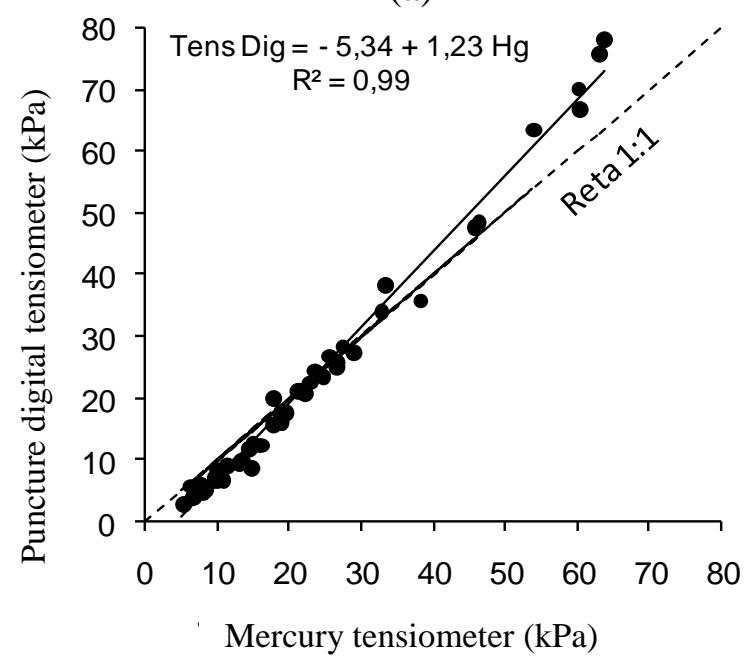

(c)

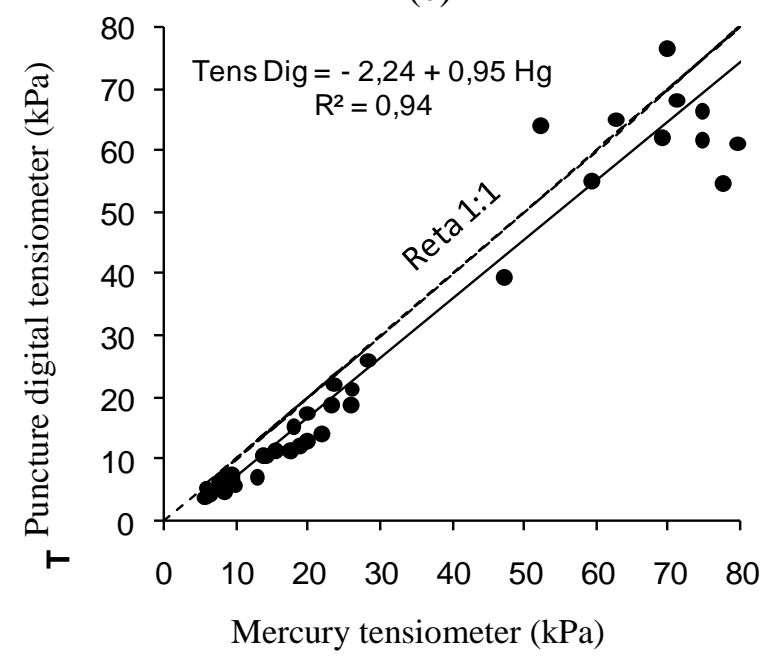

(b)

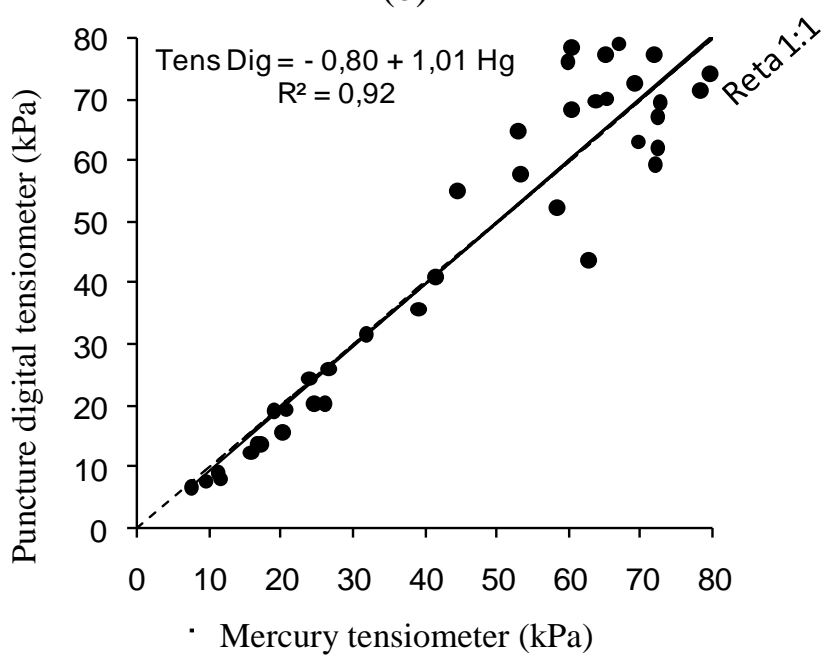

(d)

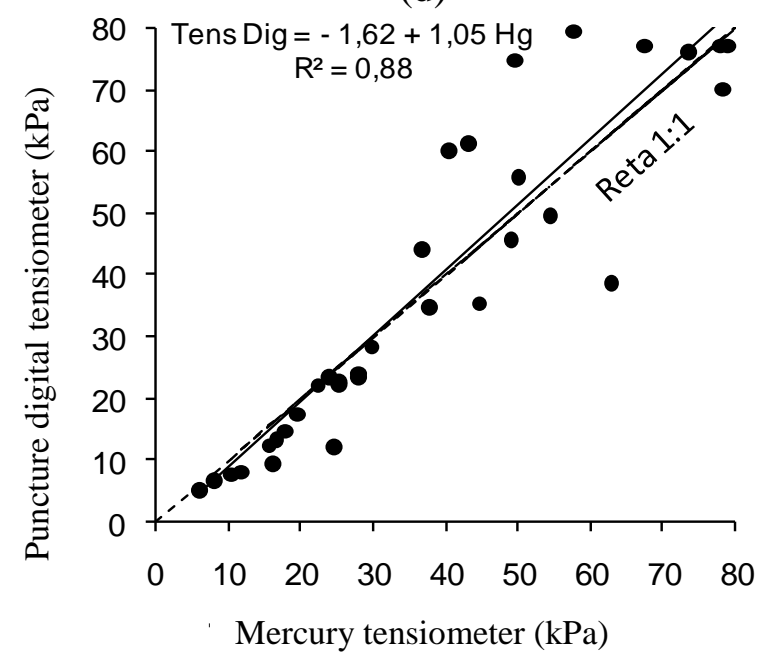

FIGURE 3. Regression and correlation analysis between the soil water matric potential (module) by mercury tensiometer and puncture digital tensiometer in plots P1 (a) P2 (b), P3 (c) and P4 (d).

The observed values of the concordance indexes and linear correlation used $(\mathrm{d}, \mathrm{r}, \mathrm{EF}, \mathrm{MAE}$ and SRMSE) were high, indicating that the results obtained with puncture digital tensiometer correspond to the values obtained with the mercury tensiometer (Table 4). However, the highest values were observed in the plot P1 and the lowest in the plot P4, which suggests that, with the wetting of the soil, the value of matric potential obtained from the two reading systems tend to have more similar results. A perfect match occurs when $\mathrm{d}, \mathrm{r}$ and $\mathrm{EF}$ are equal to 1.00 and MAE and SRMSE are equal to zero.

Considering the evaluation period and the values of soil moisture obtained by tensiometry and by the technique of neutron moderation, it appears that both methods respond similarly to changes (increase or decrease) in their values. However, soil moisture measured by the two systems of tensiometry showed more similar values between each other and, in most cases, higher when compared to those obtained with the technique of neutron moderation (Figure 4). The radius of influence of the neutron probe is higher when compared to that of the porous capsule of the tensiometer, providing measures in a larger volume of soil.

The major difference between moisture values obtained by the tensiometry and by the technique of neutron moderation was observed in P4 (Figure 4). This result indicates that the response between the methods may differ, especially at lower soil moisture, whose replacement of 
water was not sufficient to raise the values of soil moisture. Near the operation limit of the tensiometer, the differences between the readings of the tensiometer and the probe are greater than the differences when the soil was humid.

It is observed that the values of soil moisture obtained by the technique of neutron moderation decreased from August $15^{\text {th }}$ at $\mathrm{P} 4$, whereas the values did not vary by tensiometry. Under these conditions, the tensiometer has a limitation, because its use is restricted in measuring potential values up to approximately $-80 \mathrm{kPa}$.

Under high soil moisture conditions, the tensiometry was adequate for their indirect estimation. However, the puncture digital tensiometer stood out in relation to mercury tensiometer because it presents simpler operation and maintenance, provides reading less influenced by the operator and do not use toxic product.

TABLE 4. Statistical indicators for comparison of soil water matric potential by puncture digital tensiometer based on the mercury tensiometer as reference.

\begin{tabular}{cccccc}
\hline Plot & $\mathrm{d}$ & $\mathrm{r}$ & $\mathrm{EF}$ & SRMSE & MAE \\
\hline P1 & 0.98 & 0.99 & 0.95 & 4.19 & 2.98 \\
P2 & 0.97 & 0.95 & 0.92 & 7.57 & 5.54 \\
P3 & 0.98 & 0.97 & 0.92 & 8.07 & 6.06 \\
P4 & 0.96 & 0.94 & 0.88 & 9.70 & 6.83 \\
\hline
\end{tabular}

P1, P2, P3, P4: experimental plots; d: Willmott concordance index; r: correlation coefficient; EF: efficiency; SRMSE: square root of the mean square error; MAE: mean absolute error.

(a)

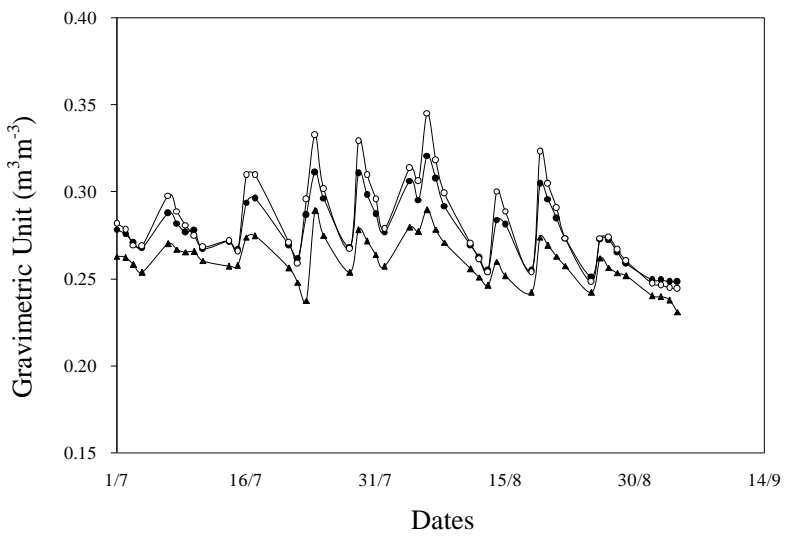

(c)

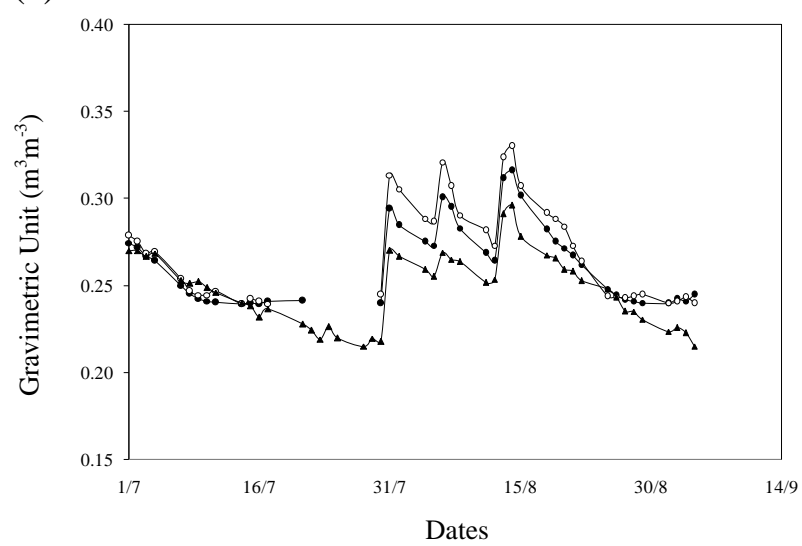

(b)

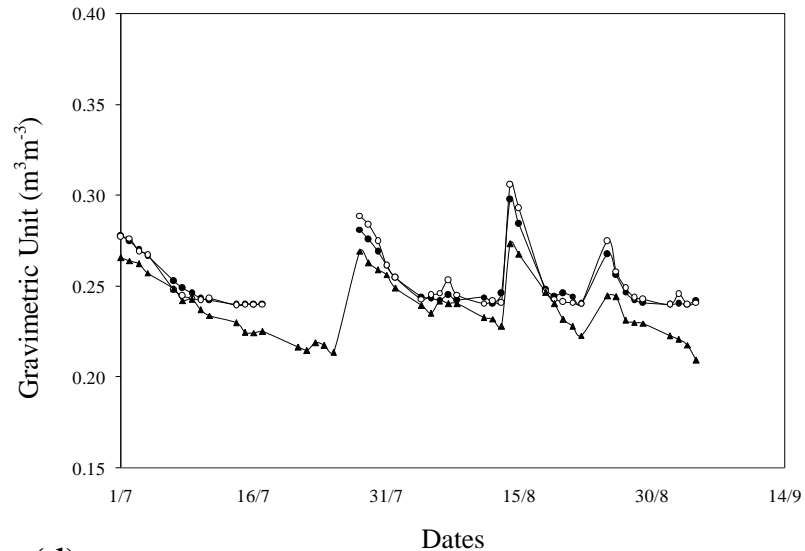

(d)

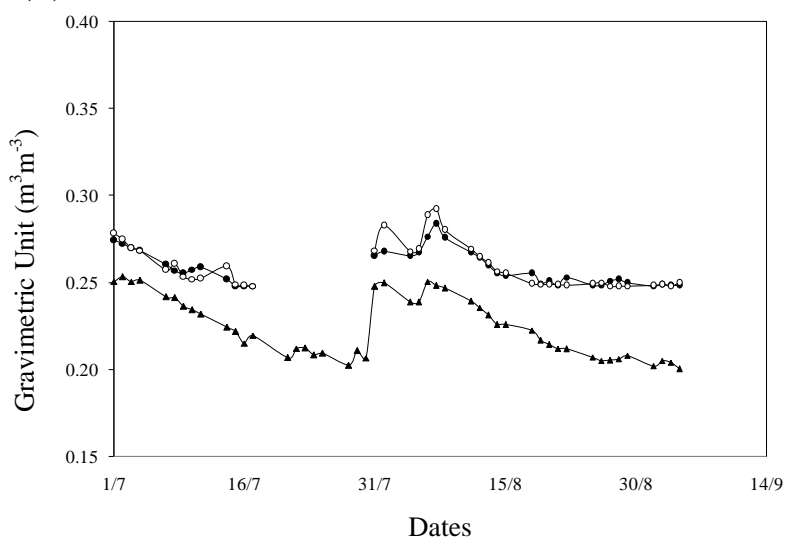

$\multimap$ Tens Hg $\multimap$-Tens Dig $\multimap$ Probe

FIGURE 4. Mean values from gravimetric soil moisture measured by mercury tensiometer (Tens $\mathrm{Hg}$ ), puncture digital tensiometer (Tens Dig) and neutron probe (Sonda) in plots P1 (a) P2 (b), P3 (c) and P4 (d). 
The results of this study indicate that the puncture digital tensiometer may be used to monitor the soil water matric potential under field conditions, with similar results to those obtained with the mercury tensiometer. However, it is recommended periodic maintenance of the silicone rubber to prevent air entering the system.

\section{CONCLUSIONS}

The soil water matric potential measured with the puncture digital tensiometer showed no difference compared to values obtained by mercury tensiometer for potential greater than $-40 \mathrm{kPa}$.

With cycles of soil wetting and drying, the matric potential obtained by puncture digital tensiometer was lower than the values obtained by mercury tensiometer.

\section{ACKNOWLEDGEMENT}

To the Coordination of Improvement of Higher Education Personnel (CAPES) for the scholarship granted.

\section{REFERENCES}

ALBUQUERQUE, P.E.P.; DURÃES, F.O.M. Uso e manejo de irrigação. Sete Lagoas: Empresa Brasileira de Pesquisa Agropecuária, 2008. 528 p.

ASSIS JÚNIOR, R.N.; REICHARDT, K. Determinação do potencial mátrico da água no solo por tensiômetro de câmara de ar. In: CONGRESSO BRASILEIRO DE CIÊNCIAS DO SOLO, 26. 1997, Rio de Janeiro. Anais... Rio de Janeiro: Sociedade Brasileira de Ciência do Solo, 1997. 1 CDROM.

BERALDO, J.M.G.; FERNANDES, E.J.; CORÁ, J. E. Tempo de contagem para determinação da atenuação de nêutrons em condições de campo. In: CONGRESSO BRASILEIRO DE CIÊNCIA DO SOLO, 32., 2009, Fortaleza. Anais... Fortaleza: Sociedade Brasileira de Ciência do Solo, 2009. 1 CD-ROM.

BRITO, A.S.; LIBARDI, P.L.; MOTA, J.C.A.; MORAES, S.O. Desempenho do tensiômetro com diferentes sistemas de leitura. Revista Brasileira de Ciência do Solo, Viçosa-MG, v.33, n.1, p.1724, 2009.

CHRISTIANSEN, J.E. Irrigation by sprinkling. Berkley: University of California, 1942. 124 p.

CICHOTA, R.; HURTADO, A.L.B.; DE JONG VAN LIER, Q. Performance of a multi-level TDR system exposed to tropical field conditions - A time-space comparison with tensiometry. Journal of Hydrology, Amsterdam, v.352, n.2, p.181-190, 2008.

COELHO, S.L.; TEIXEIRA, A. Avaliação do tensiômetro eletrônico no monitoramento do potencial matricial de água no solo. Engenharia Agrícola. Jaboticabal, v.24, n.3, p.536-545, 2004.

CRUZ, T.; TEIXEIRA, A.S.; CANAFISTULA, J.F.; SANTOS, C.C.; OLIVEIRA, A.D.S.; DAHER, S. Avaliação de sensor capacitivo para o monitoramento do teor de água do solo. Engenharia Agrícola, Jaboticabal, v.30, n.1, p.33-45, 2010.

EMBRAPA. EMPRESA BRASILEIRA DE PESQUISA AGROPECUÁRIA. Manual de métodos de análise de solo. Rio de Janeiro, 1997. 212 p.

EMBRAPA. EMPRESA BRASILEIRA DE PESQUISA AGROPECUÁRIA. Sistema brasileiro de classificação de solos. Rio de Janeiro, 2006. 306 p.

FERNANDES, E.J. Comparação entre três métodos para estimar lâminas de irrigação. Irriga, Botucatu, v.13, n.1, p. 36-46, 2008.

GEE, G.W.; BAUDER, W. Particle-size analysis. In: BLACK, C.A. Methods of soil analysis. Madison: American Society of Agronomy, part 1. 1986. (Agronomy, 9). 
GENUCHTEN, M.T.A. Van. A closed-form equation for predicting the hydraulic conductivity of unsaturated soils. Soil Science Society of America Journal, Madison, v.44, n.5, p.892-897, 1980.

KLUTE, A. Water retention: Laboratory methods. In: KLUTE, A. (Ed.). Methods of soil analysis. $2^{\text {nd }}$ ed. Madison: American Society of Agronomy, 1986. part 1, p. 635-662.

LIBARDI, P.L. Dinâmica da água no solo. São Paulo: Editora da Universidade de São Paulo, 2005. $329 \mathrm{p}$.

MARINHO, F.A.M.; TAKE, W.A.; TARANTINO, A. Measurement of matric suction using tensiometric and axis translation techniques. Geotechnical and Geological Engineering, London, v.26, n.6, p.615-631, 2008.

MARTHALER, H.P.; VOGELSANGER, W.; RICHARD, F.; WIERENGA, P.J. A pressure transducer for field tensiometers. Soil Science Society of America Journal, Madison, v.47, n.4, p.624-627, 1983.

MORAES, N.B.; MEDEIROS, J.F.; LEVIEN, S.L.A.; OLIVEIRA, A.M.S. Avaliação de cápsulas de cerâmica de instrumentos de medida de tensão usados em tensiômetros. Revista Brasileira de Engenharia Agrícola e Ambiental, Campina Grande, v.10, n.1, p.58-63, 2006.

REICHARDT, K.; TIMM, L. C. Solo, planta e atmosfera: conceitos, processos e aplicações. São Paulo: Editora Manole, 2004. 478 p.

TEIXEIRA, C.F.A.; MORAES, S.O.; SIMONETE, M.A. Desempenho do tensiômetro, TDR e sonda de nêutrons na determinação da umidade e condutividade hidráulica do solo. Revista Brasileira de Ciência do Solo, Viçosa-MG, v.29, n.2, p.161-168, 2005.

WHALLEY, W.R.; LOCK, G.; JENKINS, M.; PELOE, T.; BUREK, K.; BALENDONCK, J.; TAKE, W.A.; TUZEL, İ.H. \& TUZEL, Y. Measurement of low matric potentials with porous matrix sensors and water-filled tensiometers. Soil Science Society of America Journal, Madison, v.73, n.6, p.1796-1803, 2009.

WILLMOTT, C.J.; CKLESON, S.G.; DAVIS, R.E.; FEDDEMA, J.J.; KLINK, K.M.; LEGATES, D.R.; O'DONNELL, J.; ROWE, C.M. Statistics for the evaluation and comparison of models. Journal of Geophysical Research, Washington, v.90, n.5, p.8995-9005, 1985.

ZACHARIAS, S.; HEATWOLE, C.D.; COAKLEY, C.W. Robust quantitative techniques for validating pesticide transport models. Transactions of the ASAE, St. Joseph, v.39, n.1, p.47-54, 1996. 